\title{
INFLUENCE OF ENVIRONMENTAL FACTORS IN THE COMPOSITION OF ESSENTIAL OILS CONTENT OF JUNIPERUS COMMUNIS L. BERRIES, IN SOUTHEAST PART OF ALBANIA
}

\author{
Arlinda Agastra $^{1 *}$, Belul Gixhari ${ }^{2}$, Najada Kadiasi $^{1}$, Alban Ibraliu ${ }^{1 *}$ \\ ${ }^{1}$ Agricultural University of Tirana, Department of Agronomic Sciences, Tirana, Albania; \\ ${ }^{2}$ Albanian Gene Bank, Agricultural University of Tirana, Tirana, Albania;
}

*Corresponding Author Alban Ibraliu, e-mail: albanibraliu@ubt.edu.al; arlinda.agastra@gmail.com;

Received August 2021; Accepted September 2021; Published October 2021;

DOI: $\underline{\text { https://doi.org/10.31407/ijees11.436 }}$

\begin{abstract}
Juniperus communis L. is a widely spread scrub throughout the territory of Albania. Berries export plays an important role in the economic aspect of the population of Albania. Juniper fruits were collected from five wild population in the South region of Albania: Voskopoje, Erseke, Leskovik, Miras with the aim of investigating the effect of environmental factors and soil composition elements on the chemical composition and the natural variation of the essential oils between. The Juniper berries are collected at them same natural sites for two years (2017-2018 dried in the shade at room temperature and the essential oil was obtained by hydrodistillation in a Clevenger apparatus for $4 \mathrm{~h}$ at a distillation rate of $3 \mathrm{~mL}$.min-1. The essential oil components were identified by GC-FID and GC/MC analysis. The EO yield differed depending on the population origin and ranged between $1.5-3 \%$ on the first year based on the dry weight ( $\mathrm{v} / \mathrm{w}$, based on the dry weight) and during the second year the essential oils content varied at a range 1.6-2.8 \%. The principal components of the Juniperus communis L. berries essential oils were $\alpha$ pinene, myrcene, $\beta$-pinene, sabinene, limonene, terpinene-4-ol, belonging mainly to monoterpenes class. The dominant component was $\alpha$-pinene present in all the samples taken in consideration. Referred to the statistical analyses held in this study we assumed that in populations of Juniperus communis L. the environmental factors have a significant affect in the quantity, quality and composition of the essential oils concluding that soil types and specific elements like PH and humus content had had effected on chemical constitutions of essential oil in the investigated populations. According to the results and to the composition of EO in juniper berries in southeast part of Albania we can assign that it belongs to $\alpha$-pinene chemotype.
\end{abstract}

Keywords: Albania, Juniperus communis, essential oils, soil composition 